\title{
Commercialisation of Rice Farming in Northeast Thailand
}

\author{
Pornsiri Suebpongsang, Benchaphun Ekasingh, \\ and Rob Cramb
}

Rice has been central to the culture, economy, and politics of Thailand for more than a millennium. Thailand has long been ranked as the sixth largest producer of rice after China, India, Indonesia, Bangladesh, and Vietnam (FAO 2019), all of which have much larger populations. The dominance of rice in Thailand's agricultural economy reflects both the suitability of the natural environment for rice production and the historical origins of Thai agriculture in the long-term migrations of rice-growing populations from southern China (Falvey 2000; Chap. 1). In the 1950s and 1960s, over two thirds of the population lived in rice-producing households and a significant percentage of the remainder was involved in rice trading, transporting, and milling (Behrman 1968). Despite the

\footnotetext{
P. Suebpongsang $(\varangle) \bullet B$. Ekasingh

Faculty of Agriculture, Department of Agricultural Economy and Development, Chiang Mai University, Chiang Mai, Thailand

e-mail: pornsiri.s@cmu.ac.th

R. Cramb

School of Agriculture and Food Sciences, University of Queensland, St Lucia, QLD, Australia

e-mail: r.cramb@uq.edu.au

(C) The Author(s) 2020

R. Cramb (ed.), White Gold: The Commercialisation of Rice

Farming in the Lower Mekong Basin, https://doi.org/10.1007/978-981-15-0998-8_2
} 
growth of other crop and livestock industries in subsequent decades and a decline in rice consumption per capita as incomes have grown, rice remains the dominant agricultural industry, accounting for $51 \%$ of cultivated area and contributing 15\% of agricultural GDP (Pongsrihadulchai 2018).

Not only is rice still a vital food crop domestically but it is also a major export, second only to rubber in value. Thailand became a major exporter of rice following the opening up of the country to global trade in the 1850s (Owen 1971). ${ }^{1}$ The volume of rice exports increased fivefold between 1870 and 1905, virtually all coming from the central plain of the Chao Phraya Basin with its fertile soils, developed canal system, and close proximity to the port at Bangkok (Dohrs 1988). Rice exports surged again in the post-war period. In the 1950s and 1960s, rice accounted for $43 \%$ of total export revenue (Behrman 1968) and rice export taxes contributed more than $11 \%$ of government revenues or about USD 40 million per year (Falvey 2000). For most of the post-war period Thailand has been the world's largest exporter of rice, until being overtaken by India in 2017. Thai rice is renowned for its quality, including conventional white rice and Thai fragrant or jasmine rice (kao hom mali or kao dok mali), derived from the local variety, KDML105.

Whereas the Central Region remains the largest producer of rice for the domestic and export markets, this section focuses on the Northeast Region, or Isan, which lies within the Lower Mekong Basin (Fig. 2.1). White rice is produced mainly in the Central Region whereas jasmine rice predominates in the Northeast Region to which it is more suited. It is the high profitability of the KDML105 variety and the productivity of a related glutinous variety (RD6) that has helped spread a "fragrant aroma" over the countryside of the Northeast since the 1980s, permitting widespread commercialisation that has helped lift many rural households out of poverty and spurred wider economic development in what has long been regarded as a backward region (Barnaud et al. 2006; Grandstaff et al. 2008; Rigg et al. 2012; Rambo 2017).

In this chapter we analyse the broad trends in the commercialisation of rice farming in the Northeast in the context of the country as a whole, considering production, marketing, and policy dimensions. The following two chapters present aspects of rice farming in Ubon Ratchathani Province, located in the southeastern corner of the Northeast Region on the floodplain of the Mun-Chi river system just before it enters the Mekong (Fig. 2.1). This is one of the leading rice-producing provinces in Thailand and encapsulates the diverging trends among Thai rice farmers in the 2010s. 


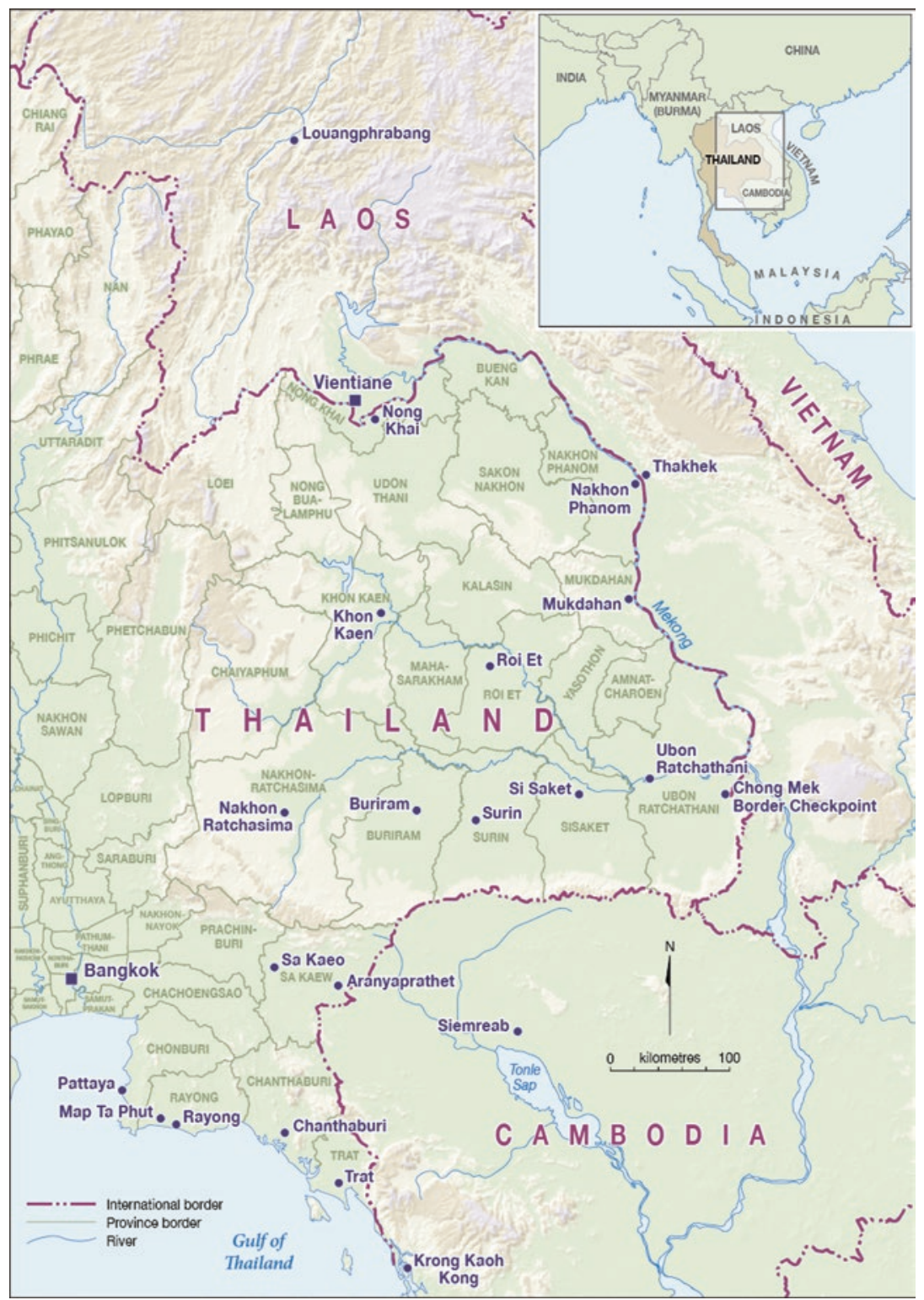

Fig. 2.1 Northeast Thailand. (Source: CartoGIS, Australian National University) 


\section{Rice Production}

Northeast Thailand encompasses the flat to undulating lands of the Khorat Plateau between the Phetchabun Range in the west and the Mekong River in the east (Wada 2005). These lands are conventionally classified into high, middle, and low terraces, with different susceptibilities to drought and flood and hence different suitabilities for rice and field crops. Most of the arable soils in the Plateau are sandy, acidic, and infertile, comprising mainly quartz and kaolinite from highly weathered parent materials. Originally covered with monsoonal dipterocarp forests, progressive clearing for farming has led to a decline in soil organic matter and mineral nutrients and an increase in soil acidity. Much of the arable land is also salt-affected to varying degrees-strongly in the hilly to undulating regions in the west and weakly in the flat low-lying areas along the Mun and Chi Rivers.

As elsewhere in the Lower Mekong Basin, there are two main growing seasons for rice in the Northeast-the wet season and the dry season. Most paddy land is rainfed and can only support a crop of rice in the wet season (May to October). The contrast between the wet and dry seasons is greater in Northeast Thailand than in many other parts of Mainland Southeast Asia (Heckman 1979). During the wet season rainfall is erratic but can be so frequent and heavy that local flooding often results. These floods and the occasional overflow of the Mekong and its major tributaries can destroy crops but also bring about renewal of the topsoil, maintaining the fertility of the lower terraces. In contrast, the lack of rainfall in the dry season greatly limits plant growth in the absence of irrigation (Heckman 1979). Only $10 \%$ of the cultivated area in the Northeast is irrigated (Molle et al. 2009) compared with over $50 \%$ in the Central Region (Pongsrihadulchai 2018).

The Northeast Region contains $46 \%$ of the agricultural holdings in Thailand and $47 \%$ of the farm area, with an average holding size of 3.2 ha (Table 2.1). Though the Northeast is less favourably endowed for rice production in terms of soil and water resources, rice accounts for over two thirds of land use-more than in any other region-with field crops (cassava, sugarcane, and maize) making up a further $20 \%$ (Table 2.2). In 2017, $63 \%$ of all rural households in the Northeast produced some rice. Most of these produced glutinous or sticky rice, which has long been the preferred staple of the predominantly ethnic Lao population. ${ }^{2}$ Almost half the glutinous rice produced is consumed by the household, compared to no more 
Table 2.1 Number and area of agricultural holdings in Thailand by region, 2013

\begin{tabular}{|c|c|c|c|c|c|}
\hline \multirow[t]{2}{*}{ Region } & \multicolumn{2}{|c|}{ No. of holdings } & \multicolumn{2}{|c|}{ Area of holdings } & \multirow{2}{*}{$\frac{\text { Area per holding }}{\text { ha }}$} \\
\hline & No. & $\%$ & $b a$ & $\%$ & \\
\hline Central & 847,163 & 14.3 & $3,136,686$ & 16.8 & 3.7 \\
\hline North & $1,298,468$ & 22.0 & $4,401,677$ & 23.6 & 3.4 \\
\hline Northeast & $2,744,457$ & 46.4 & $8,737,201$ & 46.8 & 3.2 \\
\hline South & $1,021,479$ & 17.3 & $2,384,222$ & 12.8 & 2.3 \\
\hline Total & $5,911,567$ & 100.0 & $18,659,786$ & 100.0 & 3.2 \\
\hline
\end{tabular}

Source: Agricultural Census 2013

Table 2.2 Agricultural land use in Thailand by region, 2013 (\% of area)

\begin{tabular}{lrrrrrr}
\hline Land use & Central & North & Northeast & South & Total (2003) & Total (2013) \\
\hline Rice & 42.4 & 50.1 & 67.5 & 5.7 & 52.9 & 51.3 \\
Field crops & 27.2 & 34.8 & 20.5 & 0.3 & 18.5 & 22.4 \\
Rubber & 8.5 & 3.2 & 8.2 & 66.7 & 8.9 & 14.5 \\
Permanent crops & 13.1 & 7.7 & 0.9 & 24.2 & 10.5 & 7.5 \\
Forest (planted) & 1.5 & 1.5 & 0.6 & 0.2 & 1.0 & 0.9 \\
Horticulture & 2.0 & 1.1 & 0.3 & 0.6 & 1.4 & 0.8 \\
Fish culture & 2.9 & 0.2 & 0.2 & 0.4 & 1.1 & 0.7 \\
Pasture & 0.4 & 0.3 & 0.2 & 0.1 & 1.0 & 0.2 \\
Other & 2.0 & 1.1 & 1.6 & 1.9 & 5.1 & 1.6 \\
Total & 100.0 & 100.0 & 100.0 & 100.0 & 100.0 & 100.0 \\
\hline
\end{tabular}

Source: Agricultural Census 2013

than $20 \%$ of non-glutinous rice (ACI 2005). Most of the remainder is marketed within the region, especially to farmers who specialise in planting the non-glutinous jasmine rice. Around $10 \%$ of glutinous rice production is exported from the Northeast to neighbouring countries, especially Laos, where glutinous rice is also the preferred staple (Chap. 5).

The improved glutinous variety RD6, which was released in 1978, gives a higher and more stable yield than traditional glutinous varieties and was widely adopted from the late 1980s. In 1995 RD6 accounted for 83\% of the area planted with glutinous rice in the Northeast and about $40 \%$ of the total wet-season area of all types of rice (Agrifood Consulting International 2005). The higher yield from RD6 meant that farmers needed less land to meet their subsistence targets and so could devote more land to commer- 
cial rice, notably the fragrant variety KDML105 from which jasmine rice is produced, or other crops such as cassava and sugarcane. This was the basis of the growing prosperity in the Northeast (Grandstaff et al. 2008; Rambo 2017).

As noted above, most of the non-aromatic white rice for the domestic and export markets is produced in the irrigated areas of the Central Region, whereas most of the fragrant KDML105 rice is produced under rainfed conditions in the Northeast. Though lower-yielding than the main white rice varieties, KDML105 attracts a price premium, which can be two or three times the price of white rice. The contrast between the economics of non-aromatic white rice and the fragrant KDML105 can be seen in Table 2.3, showing the average costs and returns for the 2018 wet season. The yield of KDML105 was 70\% lower but this was offset by a $60 \%$ higher price, resulting in a higher gross revenue and net return. In the case of white rice, the computed net return was negative. This probably reflects the inclusion of a market wage for family labour in the total cost, which typically overstates the true opportunity cost of labour.

The "rainfed revolution" in the Northeast has involved not only the widespread adoption of improved varieties but the rapid mechanisation of production, lagging the Central Plain by perhaps a decade (Grandstaff et al. 2008; Viboon and Chamsing 2009; Rambo 2017). In the 1980s, multipurpose two-wheeled tractors began to replace buffaloes as the source of draught power for land preparation. Now medium-sized fourwheeled tractors are becoming more common. By the 1990s combine harvesters were being widely used, superseding the use of mechanical threshers. At first mechanical harvesting services were provided by contractors from the Central Region but soon a local contracting business emerged. The peak labour requirement for transplanting was overcome by

Table 2.3 Average returns to white rice and fragrant rice production in the 2018 wet season

\begin{tabular}{lll}
\hline Variable & White rice & KDML105 \\
\hline Yield (t/ha) & 2.56 & 1.81 \\
Farm-gate price (THB/t) & 9482 & 15,267 \\
Gross return (THB/ha) & 24,274 & 27,633 \\
Total costs (THB/ha) & 24,945 & 22,480 \\
Net return (loss) (THB/ha) & $(671)$ & 5153 \\
\hline
\end{tabular}

Source: Office of Agricultural Economics (2018a) 
the use of broadcasting in rainfed areas, whereas in irrigated areas transplanting machines have begun to be used. The release of labour from these tasks gave households more scope to engage in off-farm and nonfarm work, generating additional income to enable the purchase of inputs and hiring of machinery services.

In addition, beginning in the 1990s, many farmers have dug small ponds adjacent to their paddy fields to store water for supplementary irrigation using portable diesel pumps (Grandstaff et al. 2008; Rambo 2017). By the end of that decade there were 65,000 farm ponds and in 2004 the government set up a revolving fund with the aim to increase the number to 450,000 . The ponds enabled farmers to irrigate the wet-season crop during drought periods, thus helping to stabilise wet-season yields. This in turn enabled them to reduce the area planted to their subsistence crop of glutinous rice and allocate more land to KDML105 or to commercial field crops. In addition, the ponds permitted cultivation of short-term, highvalue horticultural or field crops in the dry season on a small part of the paddy field, typically generating a higher return to labour and capital than a crop of dry-season rice.

The annual output of paddy in the Northeast has more than doubled over the past four decades, from 5.8 million $\mathrm{t}$ in 1980 to a peak of 15.1 million $t$ in 2011, dropping back to $12-13$ million $t$ in subsequent years (Fig. 2.2). The growth in output since the 1980s was due to an increase in wet-season area from 4.5 million ha in 1980 to 5.9 million ha in 2018

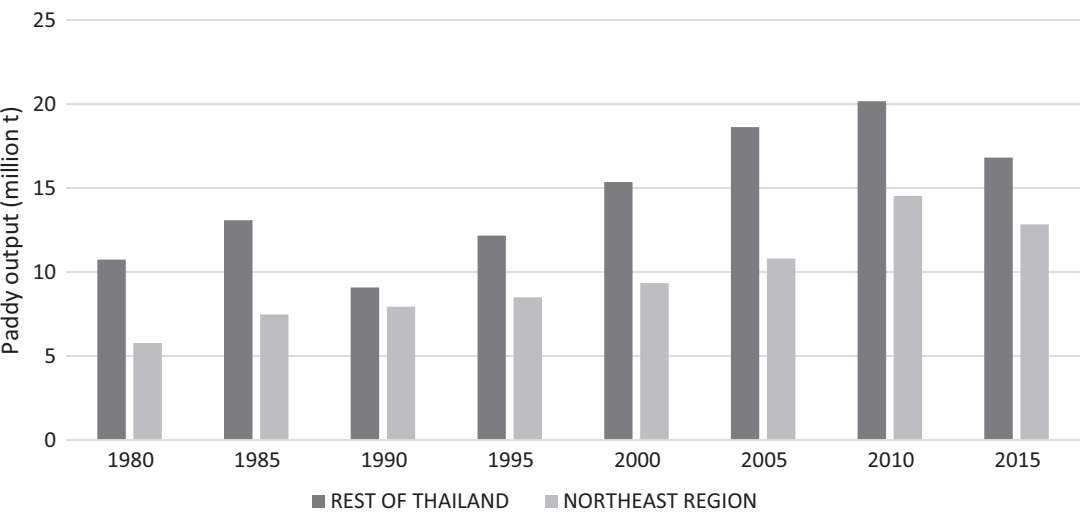

Fig. 2.2 Annual rice production in Northeast Thailand and remainder of country, 1980-2015 (million t) 
Table 2.4 Area, output, and yield of rice in Northeast Thailand compared with Thailand as a whole, by season (2018)

\begin{tabular}{lrcc}
\hline Variable & Thailand & Northeast Region & Northeast \% \\
\hline Wet-season area (million ha) & 9.47 & 5.85 & 61.8 \\
Wet-season output (million t) & 24.22 & 11.02 & 45.5 \\
Wet-season yield (t/ha) & 2.56 & 1.88 & 73.4 \\
Dry-season area (million ha) & 1.93 & 0.28 & 14.5 \\
Dry-season output (million t) & 7.96 & 1.02 & 12.8 \\
Dry-season yield (t/ha) & 4.12 & 3.60 & 87.4 \\
Annual area (million ha) & 11.43 & 6.13 & 53.6 \\
Annual output (million t) & 32.18 & 12.04 & 37.4 \\
Average yield (t/ha) & 2.82 & 1.96 & 69.5 \\
\hline
\end{tabular}

Source: Office of Agricultural Economics (2018b)

as farmers cleared more village forest lands for paddy fields; an increase in dry-season (irrigated) area from 11,000 ha to 282,000 ha over the same period, reflecting public investment in mainly pump-irrigation schemes; and an increase in yields, from 1.3 to $1.9 \mathrm{t} / \mathrm{ha}$ in the wet season and from 2.2 to $3.6 \mathrm{t} / \mathrm{ha}$ in the dry season, reflecting the wider use of improved varieties and greater use of fertilisers (Table 2.4).

The Northeast contributed $35 \%$ of total paddy output in 1980 , rising to $47 \%$ in 1990 before dropping to between $37 \%$ and $43 \%$ in subsequent years (Fig. 2.2). In 2018, the Northeast accounted for $62 \%$ of wet-season planted area and $46 \%$ of wet-season output, reflecting that the yield was only $73 \%$ of the national average (Table 2.4). The contribution of the Northeast to national dry-season production was less, given the lower proportion of irrigated paddy land, amounting to $15 \%$ of total dry-season area and $13 \%$ of output. Dry-season yields were higher at $87 \%$ of the national average. On an annual basis, in 2018 the Northeast accounted for $54 \%$ of planted area and $37 \%$ of output, with annual yields at $70 \%$ of the national average.

\section{Rice Marketing}

With the growth of production in the Northeast since the 1980s, the marketing of rice has expanded and developed. A study analysing the flow of paddy and rice in the 2000s gives an indication of how the marketing chain had evolved to that point (ACI 2005; Fig. 2.3). The 9.5 million t of 


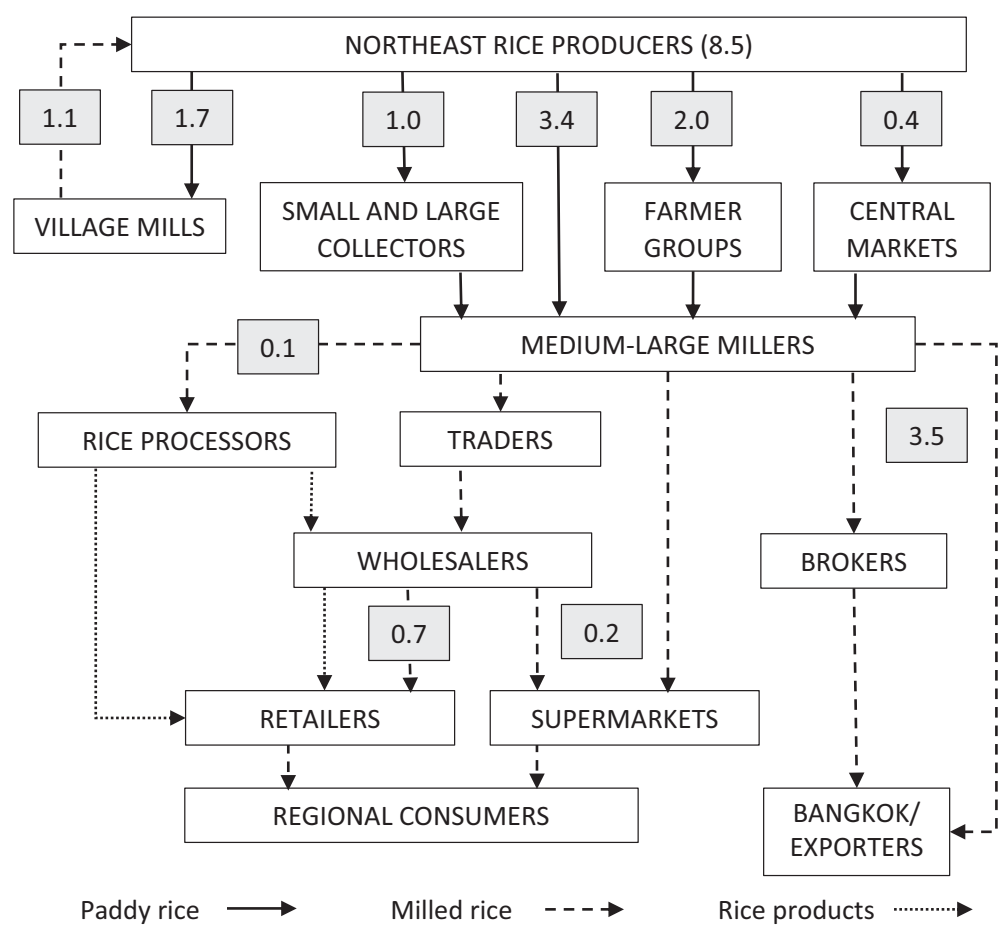

Fig. 2.3 Marketing chain for rice produced in Northeast Thailand. (Note: Numbers refer to million t of paddy or milled rice ACI 2005)

paddy produced in 2003 was traced along two channels-a subsistence channel and a market channel. Of the 8.5 million t of paddy available after deducting seed, animal feed, and losses, about one fifth was retained by farmers for household consumption (mostly glutinous rice) and four fifths was marketed commercially (mostly KDML105 and other non-glutinous rices). Farmers milled paddy for their own consumption at small village mills. Given an estimated recovery rate of $65 \%$, about 1.1 million $t$ of milled rice was consumed by producing households.

About 6.8 million $t$ of paddy was thus available for marketing. There were several pathways for farmers to dispose of their marketable surplus. The traditional method was to sell to primary collectors, including smallscale village collectors without warehouses and larger-scale collectors at the district and provincial levels who had their own warehouses. Collectors 
were located close to producing areas and transported paddy in pick-ups or six-wheeled trucks. However, these accounted for only $15 \%$ of the paddy sold. About $5 \%$ of paddy was sold through central markets, operated by both public agencies (such as the Bank for Agriculture and Agricultural Cooperatives) and private entrepreneurs. ${ }^{3}$ These served as a meeting place to conduct transactions. Facilities provided could include labour, moisture gauges, drying yards, warehouses, and loans, depending on the size of the centre. The market owners were sometimes also assemblers and/or millers, though the owner of a large central market usually refrained from trading to avoid price interference, relying on fees, rent, and interest from loans. A much larger share of the surplus (80\%) was sold directly to millers, representing the most striking change that has occurred with commercialisation. This included $50 \%$ sold by farmers operating on their own account and 30\% sold through farmer groups or cooperatives (Wiboonpongse and Chaovanapoonphol 2001). Using a recovery rate of $65 \%$, the 6.8 million t of paddy channelled to mills produced 4.4 million $t$ of milled rice.

Over half the rice mills in Thailand are located in the Northeast Region, totalling 24,000 in 2003 (Agrifood Consulting International 2005). However, about $98 \%$ of these were small-scale or village custom mills (less than $5 \mathrm{t} /$ day) and only $2 \%$ were medium- to large-scale private or cooperative mills. Only about $1 \%$ of mills in the region had a capacity of more than $50 \mathrm{t} /$ day; two mills could operate at $1000 \mathrm{t} /$ day. Large mills with storage capacity could stockpile paddy during the harvesting period when there was excess supply and process and sell it when the price increased (Rabobank 2003). While village mills still predominate, investment in large, modern mills in the Northeast has increased in the decade or so since this study.

After milling, rice followed different channels for the domestic and export markets (ACI 2005). The milled rice for the domestic channel was sold to traders, wholesalers, and directly to retailers. There were also various markets for the by-products of milling such as rice bran. Of the 4.4 million $t$ of milled rice produced in 2003, about 1 million $t(23 \%)$ went into the regional market, whether for retail sales $(90 \%)$ or further processing into rice-based products $(10 \%)$. Much of the domestic market was provided by the $40 \%$ of Northeast farmers who specialised in producing KDML105 rice for the export market and therefore needed to buy glutinous rice for their own consumption (ACI 2005). The remaining 3.4 million $t$ of milled rice went through traders and wholesalers to mar- 
kets outside the region, including both Bangkok and surrounding areas and the export market. Most millers, except for a few large firms, sold rice to wholesalers and exporters through a broker. The broker was commissioned to search for quantities of rice of specified qualities to meet the requirements of wholesalers and exporters, charging a brokerage fee of $2-3 \%$ of the sale value.

The retail distribution system for food, including rice, is undergoing rapid change in Thailand. Alongside the traditional food markets, modern distribution systems are emerging, including supermarkets, superstores, and convenience store chains. Whereas in the traditional retail market rice is sold loose and customers can purchase any quantity, in supermarkets rice is sold in labelled packages of fixed sizes such as $5 \mathrm{~kg}$ bags. In the 2000s, $75 \%$ of the retail food trade was still through traditional markets (ACI 2005), with modern distribution channels mostly limited to major urban centres. Nevertheless, the number of supermarkets and other modern retail outlets in the Northeast is increasing.

Most exporters are located in Bangkok and surrounding areas (ACI 2005). Many exporters have their own rice mills, while those without mills deal directly with large mills or depend on brokers who can guarantee an adequate supply of a specified type and quality of rice. Most exports are handled by private companies, who must be registered under the provisions of the Rice Trading Act. Only around 5\% of exports are handled by state agencies. Each exporter has connections to particular importers demanding a given type and quality of rice. For example, exporters of Thai jasmine rice have standing arrangements with importers in Hong Kong, Singapore, and the Middle East. Thailand exports mostly to Africa and Asia, with the African market the fastest growing. In 2005 Africa accounted for $47 \%$ of total rice exports $(3.4$ million $\mathrm{t})$, followed by Asia $(28 \%$ or 2.0 million $\mathrm{t}$ ), and the Middle East ( $12 \%$ or 0.9 million $\mathrm{t}$ ). Europe accounted for only 5\% (0.3 million $\mathrm{t})$ and the US 6\% $(0.4$ million $\mathrm{t})$. Exports of Thai jasmine rice, mainly grown in the Northeast, amounted to 2.9 million $t$, or $26.1 \%$ of the total volume, in 2018 . Glutinous rice exports were only 180,159 t or $2 \%$ of the total.

\section{Rice Policy}

The commercialisation of rice farming in the Northeast has been strongly influenced by state policies affecting farmers' access to resources (land and water) and inputs (seed, fertilisers, extension, and credit), their manage- 
ment of farm activities, and their appropriation of farm output and revenue (Fig. 1.8).

\section{Land}

Private rights in land have been recognised since the nineteenth century and a land titles system was introduced in 1901, administered by the Department of Lands (DOL) (Burns 2004). Land titling was initially concentrated in the Central Plain but was gradually extended to the other parts of the country, including the Northeast, where the DOL had provincial and district offices. Title deeds were issued based on a cadastral survey. However, studies for the fifth National Social and Economic Development Plan (NSEDP, 1981-1985) found that only about 12\% of the 23.7 million ha of occupied agricultural land was held by title deeds, a further $49 \%$ was held by lesser (unsurveyed) documents, 18\% was occupied by claimants without documentation, and $21 \%$ was illegally occupied forest land. The Plan set out a strategy to grant secure tenure to agricultural landholders, noting that this would improve access to institutional credit and thus provide the basis for long-term investment by farmers. A land titling project was initiated with support from the World Bank and by 2001 a further 8.5 million titles had been issued over about 4.9 million ha (Burns 2004).

Alongside this initiative, an agricultural land reform programme was started in 1975 to redistribute land to landless farmers and provide titles to "squatters" on public lands (as much of the agricultural expansion had occurred through clearing of forest on what was regarded as public land). The Agricultural Land Reform Office (ALRO) in the Ministry of Agriculture and Cooperatives (MOAC) was responsible for land allocation and titling, and for providing domestic water supplies, village roads, farm ponds, and small-scale reservoirs and irrigation facilities (ALRO 2006). The ALRO also established Agricultural Land Reform Cooperatives, provided agricultural credit and production inputs, supported on-farm and off-farm occupations, and promoted community-based conservation of natural resources (Ekasingh et al. 2008). From 1975 to 2005, 2.1 million ha were allocated to 762,170 households in the Northeast $-52 \%$ of the total area nationally. This represented $24 \%$ of the area of farm holdings in the Northeast, as recorded in the 2013 Census, and $28 \%$ of the number of holdings.

Land has also been made available through research to improve its capability. Research by the Department of Land Development (DLD) 
within MOAC led to the amelioration of saline soil over a large area known as Thung Kula Rong Hai, mainly in Roi Et Province (Fig. 1.2). This enabled the rehabilitation of 88,000 ha to become a major area of jasmine rice production, benefitting 14,280 farm households (Ekasingh et al. 2008).

The effect of this long-term land policy has been to provide secure tenure for large numbers of rice-growing smallholders in the Northeast. While population growth and the closure of the agricultural frontier in the 1980s meant that the size of these smallholdings declined-from an average of 4.5 ha in 1980 to 4.3 ha in $1990,3.6$ ha in 2000 , and 3.2 ha in 2013 - the area per household member and per worker has remained stable, reflecting the trend to smaller families and the outmigration of younger household members (Grandstaff et al. 2008). This, combined with improvements in infrastructure, has enabled millions of smallholder farmers to capitalise on the opportunities for commercial rice farming since the 1990s. While in some areas farmers are consolidating their paddy fields into larger units to permit land levelling and greater field efficiency in the use of machinery (Rambo 2017), there has not been significant differentiation in the ownership of land. Thus in $201351 \%$ of landholdings were within the bracket 1.6 to $6.2 \mathrm{ha}$, accounting for $51 \%$ of the total farm area. As Rigg et al. (2012) have highlighted, land ownership and paddy farming remain central to household livelihood strategies, even as nonfarm sources of income become dominant.

\section{Water}

Access to irrigation has been a less important element in the commercialisation of rice farming, despite official rhetoric about "greening Isan". There has been a long-term policy focus on the development of water resources for agriculture in the Northeast as a way to intensify rice farming and reduce poverty (Molle et al. 2009; Floch and Molle 2013). Much of this has involved investment in small- and large-scale pump-irrigation schemes, managed by the Royal Irrigation Department (RID) of MOAC, to permit dry-season cropping of rice. However, investment in the required canal system has often lagged and, even where the distributional infrastructure has been satisfactorily completed, the utilisation for dry-season cropping has been much lower than predicted due to the low and variable profitability of dry-season rice (KDML105 is a wet-season variety) and the increasing scarcity of farm labour. The total irrigable area in Northeast 
Thailand is only 1.2 million ha, with limited utilisation in the dry season (Floch and Molle 2009). Thus most rice production still takes place under rainfed conditions, though increasingly with the benefit of supplementary irrigation from small ponds, as noted above.

\section{Seed}

The crucial input that has enabled the commercialisation of rice farming in the Northeast has been the selection, breeding, and dissemination of improved varieties by public agencies. The term "improved", rather than "high-yielding", is appropriate as the varieties adopted by farmers were better adapted to local conditions and/or produced higher-quality rice rather than simply increasing yields. The International Rice Research Institute (IRRI) began working in Thailand from 1966, earlier than in the other countries of the Lower Mekong Basin, but the first high-yielding, semi-dwarf variety, IR8, was not adopted because of it low eating quality. However the Rice Department (RD) of MOAC incorporated the semidwarf gene in IR8 in a series of locally bred varieties (labelled RD) that were widely adopted in the irrigated areas of the Central Plain. RDl gave a $50 \%$ higher yield but was not adopted due its poor eating quality and high input requirements. Subsequently developed photoperiod-insensitive, high-yielding varieties, especially RD7, RD15, and RD23, became dominant in the irrigated areas of the Central Region, underpinning the rapid rise in output. However, most of this additional production was not consumed domestically but exported as lower-quality white rice or used to make parboiled rice, also for export.

In the 1980s, with the emergence of Vietnam as a major exporter of low-quality rice, there was downward pressure on the international price for this type of rice, whereas the price of higher-quality rice showed an upward trend (Setboonsang 1996). This prompted rice researchers in MOAC to revive earlier efforts to select and breed for rice quality. The major breakthroughs were, as noted above, the selection and promotion of a line of local fragrant rice labelled Kao Dok Mali 105 (KDML105) and its mutagenesis to form RD6, a higher-yielding glutinous variety. Both are medium-term, photoperiod-sensitive varieties that are well adapted to the soil and climatic conditions of the Northeast and respond well to additional inputs. RD6 was rapidly adopted and, by 1995, accounted for $40 \%$ of the total wet-season rice area in the Northeast and $83 \%$ of the glutinous rice area (Ekasingh et al. 2008). By the same year, KDMLl05 accounted 
for $72 \%$ of the non-glutinous rice area, increasing to $80 \%$ in $2002-2005$ (Grandstaff et al. 2008: 332). The ability to secure subsistence with RD6 enabled farmers to allocate more land to production of KDML105 for the domestic and export markets, generating a much higher return.

The provision of improved seed to farmers was facilitated by the Department of Agricultural Extension (DOAE), which provides a linkage between researchers and extension staff. The DOAE's crop promotion project aimed for increased yields by disseminating good-quality seed of improved varieties (Ekasingh et al. 2008). One approach used was the "seed exchange method", implemented from 1982 to 1998 for rice, by which a kilogram of farmers' seed was exchanged with a kilogram of goodquality seed of an improved variety. In poorer areas, the "free rice seed" approach was used. The DOAE also initiated community seed production centres in 65 rice-producing provinces to produce good-quality seed for local dissemination.

\section{Fertilisers}

As part of the intensification of rice farming and other crop production, the use of synthetic fertilisers has increased more than tenfold, from around $20 \mathrm{~kg} / \mathrm{ha}$ in 1980 to $250 \mathrm{~kg} / \mathrm{ha}$ in 2008, though the rate of increase has slowed. More than $95 \%$ of the synthetic fertilisers used in agricultural production are imported (OAE 2011). Urea (46-0-0), used mainly for rice and vegetable crops, is the most important imported fertiliser, accounting for $35 \%$ of imports by value, while other widely used fertilisers are ammonium phosphate (16-20), accounting for 9\%, and the NPK compound fertiliser 15-15-15 (6\%). The import, mixing, and distribution of fertilisers is in private hands and is not subsidised, though the government monitors and regulates retail prices to avoid price spikes which would adversely affect farmers (Chitibut et al. 2014). This regulatory imposition has led to the emergence of a parallel informal market distributing products of variable quality.

Despite the increase in use of synthetic fertilisers, alternative approaches to nutrient management and crop protection have been promoted by the government, particularly since the 2000s. Farmers are encouraged to apply compost, green manure, animal manure, and other organic fertilisers instead of or together with synthetic fertilisers. Organic fertiliser has been adopted for many types of agricultural production, including rice farming. A survey by the Office of Agricultural Economics published in 
2010 found that about $48 \%$ of farms applied organic fertiliser together with synthetic fertiliser, while $41 \%$ used only synthetic fertiliser and $6 \%$ used only organic fertiliser. A recent industry analysis concludes: "The organic fertilizers and biofertilizers market is expected to grow as a result of the increased demand for organic food products. Government encouragement by providing subsidies and incentives for the use of organic fertilizers will drive the growth of organic fertilizers" (Mordor Intelligence 2019). The report adds that the government is encouraging private sector production of organic fertilisers and bio-fertilisers in part to reduce the dependence on imported fertilisers.

\section{Extension}

For agricultural extension, the Department of Agricultural Extension (DOAE) established in 1967 is mainly responsible for extension of crop production whereas Department of Livestock Development (DLD) and Department of Fisheries are for livestock production and aquaculture, respectively. The DOAE is directly responsible for integrating the concepts and strategies of crop promotion by cooperating with research institutes, universities, agricultural credit, marketing organisations, and other related agencies. Its tasks are to provide extension services and technology transfer to farmers to help increase farm productivity, both qualitatively and quantitatively, and to meet market demands and standards. The DOAE has established a regional office in all regions and also provincial and district offices in all provinces and all districts for the whole country. In each district, there are extension officers to work closely with farmers. District and sub-district agricultural extension officers have a duty to convey knowledge and technologies which have already tested for local adaptability from research institutions to farmers and get feedback regarding the problems and constraints, either technical or biological, being faced by farmers and farmers' attitudes, and proposed to researchers by extension officers.

In 1999, the DOAE established a new extension system in response to the new constitution law in 1997 and the 9th National Social and Economic Development Plan for giving priority to human development. The new extension system has a principle that farmers will determine the development pathway by themselves and extension officers will be facilitators and coordinators as well as learning partner of farmers. The Agricultural Technology Transfer and Service Center (ATSC) in each sub-district have 
been established throughout the whole country to be mechanisms for working with farmers as well as other related institutions such as local government, farmer associations, NGOs, and private sector in the agricultural development process. The ATSC is formulated to develop one-stop service centres for farmers and communities in the areas of agricultural development, agricultural production, market development, and natural resources management. The ATSC implementation was carried out on the basis of community-based development by providing opportunity to farmers, enabling them to participate, and promoting their potential to plan and solve existing problems by themselves. Thus, the establishment of ATSC paved the way to decentralisation and empowerment for community development (Panee Boonyaguakul and Surangsri Wapet, 2005, cited in Ekasingh et al. 2008).

\section{Credit}

As farmers became more commercialised in their activities, the demand for credit increased. There have been many sources of formal and informal credit available to farmers but the major sources have been the Bank of Agriculture and Agricultural Cooperatives (BAAC), whose operations have been strongly supported by government policies since the 1970s. By 1982, the BAAC provided credit totalling THB 12 billion to about half of the farm households in Thailand. While BAAC met the most obvious credit needs of medium-scale farmers, it had some difficulty in reaching the poorest farmers (Falvey 2000). The use of group-guaranteed loans has been an effective alternative means to lend to poor farmers who lack collateral. Credit has been used by farmers to purchase improved seeds, equipment, fertilisers, and pesticides. Out of 5.8 million farm households in 2008, 3.5 million (59.9\%) had agricultural debt. Of these, $63.5 \%$ borrowed from the BAAC, $9.2 \%$ from cooperatives, $9.9 \%$ from village funds, and $7.4 \%$ from informal sources. The average agricultural debt was THB 104,640 per household (National Statistics Office 2008).

\section{Farm Management}

Farmers in the Thailand are not subject to state direction regarding their choice of crops or production techniques. However, government policy since the 1990s has sought to persuade and subsidise farmers to shift towards "sustainable agriculture", which has been variously interpreted as 
integrated farming systems, diversified farming, good agricultural practices (GAP), or organic farming. This push has been given strong ideological support from the late King Bhumibol Adulyadej's "new theory of agriculture"-part of his philosophy of a "sufficiency economy" (Kasem and Thapa 2012). This promotes the need for farm management to provide food self-sufficiency or food security for farmers. ${ }^{4}$

The emphasis on sustainable agriculture encourages crop diversification, a shift away from agricultural intensification, reduced use of inorganic fertilisers and pesticides, and promotion of organic agriculture and healthier food. A number of programmes have been implemented in support of sustainable agriculture, including subsidised credit and training programmes for farmers who are willing to participate. In 2016, the military government's National Rice Policy and Management Committee (NRPMC) initiated a scheme that paid qualified farmers subsidies to stop planting rice in areas deemed to be unsuitable and to develop integrated farming systems, with on-farm irrigation, fish, and livestock. According to official maps, most land deemed unsuitable for growing rice is located in the Northeast, though there are doubts about the accuracy of the zoning (Sunsuk 2016). ${ }^{5}$

Concerns about the intensive use of chemical inputs in Thailand have underpinned policies promoting good agricultural practices (GAP) and food safety. GAP-certified farmers are required to use organic fertilisers together with inorganic fertilisers to ensure high-quality produce. They must also use bio-pesticides to control pest outbreaks, though they can apply inorganic pesticides if approved by the business they are contracted to supply (Kasem and Thapa 2012). The area of certified GAP land was 366,000 ha in 2008 , considerably more than the 22,000 ha certified as organic. Nevertheless, Thailand is the world's largest exporter of organic rice and some villages in the Northeast are embracing this version of sustainable agriculture (Chaps. 3 and 4 ).

\section{Marketing and Pricing}

The overwhelming policy intervention in Thailand's rice industry has been the state's involvement in the purchase and storage of paddy. In 1976 the export tax on rice was abolished and the first price support programmes were instituted. Price support developed into a rice buffer stock scheme from 1981, intended to stabilise consumer prices and raise farmgate paddy prices, and a paddy mortgage or pledging programme from 
1983, financed by the Bank for Agriculture and Agricultural Cooperatives. The latter used public warehouses or on-farm storage to carry over paddy stocks so that farmers did not have to sell immediately after harvest when prices were low. With increasing subsidisation, more farmers participated (Ekasingh et al. 2008). However, aggressive government intervention to support prices through this mechanism, first in the mid-2000s but most ambitiously from 2011 to 2014 under the government of Yingluck Shinawatra, led to the accumulation of record stocks of up to 18 million $t$ and the eventual collapse of the programme (Welcher 2017) and of the government. At its height, the scheme offered farmers prices 50-60\% above the market price, with no upper limit on purchases, thus squeezing out commercial traders, millers, and exporters and severely disrupting the export market. Stocks are still being progressively disposed of in government-to-government deals and auctioned to private buyers at discount prices, but the domestic and export markets have been able to return to some normality (Chuasuwan 2018).

Figure 2.4 traces the FOB export price of Thai Al Super white broken rice (the reference price for the world market) and of Thai Fragrant Rice over the past two decades, showing the impact of both government policies and global shocks. The figure shows the doubling in the price of white rice as part of the global food price crisis in 2008 and the subsequent even greater price spike brought about by the Thai Government's 2011-2014 stockpiling. The unavoidable release of carryover stocks combined with the continued expansion of exports from India has brought the world price down again to just above pre-2008 levels. The figure also shows the growing premium in the world market for high-quality rice, encouraging countries such as Vietnam and Cambodia to increase their share of this segment of the market (as discussed in subsequent chapters).

In 2016 the military government announced it would no longer continue with the rice pledging and income insurance programmes. Instead, short-term measures were introduced, including the "Farmer Loans to Delay the Sales of Paddy" (known as "On-Farm Paddy Pledging"), aimed at stabilising the farm-gate prices of fragrant and glutinous paddy rice. The government also approved a budget of THB 45 billion (USD 1.3 billion) under the Rice Farmer Assistance Measure to finance direct payments to farmers adversely affected by drought. Farmers in this programme also are eligible to have their BAAC debt suspended for two years at a reduced interest rate (3\% instead of the normal $7 \%$ ). Moreover, farmers who buy 


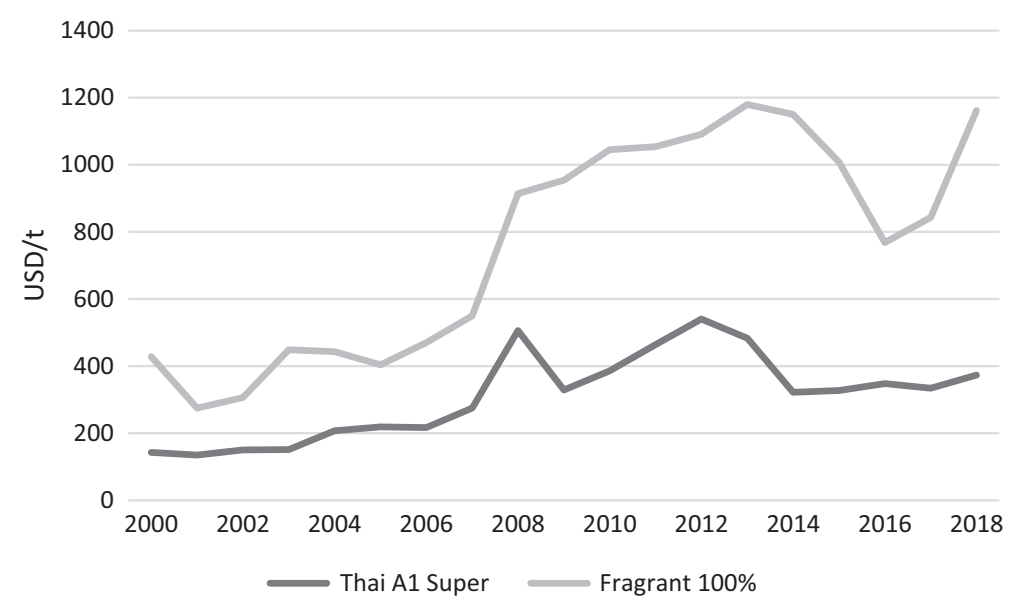

Fig. 2.4 Average export price of Thai white and fragrant rice, 2000-2018 (USD/t, FOB). (Source: IRRI-World Rice Statistics Online (http://ricestat.irri. org:8080/wrsv3/entrypoint.htm))

commercial crop insurance will receive partial compensation from the government for losses from natural disasters (Welcher 2017).

\section{Changes in Rice Farming in a Village in Khon Kaen Province}

To understand the long-term changes in rice farming in the Northeast Region, it is useful to consider a case study. Barnaud et al. (2006) studied agricultural change in Ban Hin Lad, a village in Khon Kaen Province $40 \mathrm{~km}$ northwest of Khon Kaen City (Fig. 2.1). The village was located in the undulating middle terrace of the Khorat Plateau that accounts for over $70 \%$ of the Northeast Region; hence, the farming landscape was a typical combination of uplands and lowlands. Rainfed lowland rice was preferentially cultivated in the shallow depressions with more clayey soils, called the "lower paddies", and secondarily in the adjacent "upper paddies" which were sandier and more drought-prone. Above these paddies were the more hilly "uplands" with very sandy soils, which supported dry dipterocarp forests before being cleared for cash crops, notably cassava and sugarcane. The village did not have access to the irrigation schemes that had been developed in the region since the 1960s (Floch and Molle 2009). 
A previous survey of the village had been carried out in 1983, providing a basis for comparison with the diagnostic analysis conducted by the authors in 2002. In 1998 the village had 1937 inhabitants in 383 households (averaging 5.1 residents per household) farming 1250 ha (3.3 ha per household). Barnaud et al. (2006) drew on various sources of data, in particular, interviews with 26 different types of farm household. Their data are supplemented below with data from some more recent studies in the same region.

Up to the 1960s, farming in the study village involved the cultivation of glutinous rice in bunded paddy fields for household subsistence. Each farmer combined three or four varieties of different duration to adapt to variations in the toposequence and the weather, with 28 different varieties recorded in the village as a whole. Large numbers of buffaloes were reared to provide draught power and manure for rice cultivation and as a store of wealth. Hunting and gathering in the forest and fishing in the rivers provided additional subsistence. With no rivers or canals to connect the region with the Central Plain, villagers were cut off from trading networks. In the 1960s this began to change with the construction of the Friendship Highway (Route 2) across the region and the promotion of the long-fibre crops, roselle, and kenaf, for export production. From the mid-1960s there was increased deforestation, driven in part by the expansion of these cash crops in the uplands, though forest clearance was initially limited by reliance on manual tools. The area planted to long-fibre crops began to fall away from around 1970.

Nevertheless, rapid forest clearance continued for another two decades. The area of forest cover in the Northeast fell from around 7 million ha in 1965 to around 2 million ha in 1985, with a corresponding increase in the area farmed. There were two reasons for this. First, the Northeast was experiencing rapid population growth, with the population density increasing from 55 persons per $\mathrm{km}^{2}$ in 1960 to 100 persons per $\mathrm{km}^{2}$ in 1980. The increased subsistence needs of the local population were met, not by increasing yields, but by expanding the area cultivated onto the more drought-prone transitional zone between the lowlands and the uplands, creating more "upper paddies". In addition, from around 1970, farmers began to take up cassava cultivation in the uplands in response to the booming European market. Cassava cultivation in the Northeast increased from 10,000 ha in 1969 to almost a million ha in the mid1980s. The accelerated deforestation was because of the heavy mechanisation of land clearing and tillage for cassava production, using rented 
four-wheeled tractors, and the higher land-to-labour ratio in cassava production compared with the long-fibre crops (which required very laborious post-harvest operations). As the forested land was "up for grabs", households with more resources who got in first acquired more land, creating an inequality in landholdings that was to persist in subsequent decades, affecting the subsequent pattern of mechanisation.

Despite the expansion of cultivated area, population pressure led to a reduction in farm size. The average farmed area in the study village decreased from 5.5 ha in 1983 to 3.2 ha in 1998. At the same time, nonfarm wage rates were rising, both in the Northeast and in Thailand as a whole. Real daily wages in Khon Kaen City rose from about USD 1.50 in 1973 (similar to Bangkok wages) to USD 3 in 2001 (compared to USD 3.50 in Bangkok). ${ }^{6}$ In the 1970 s, many farmers from the Northeast, particularly younger household members, migrated to the Central Plain to work as hired labourers on larger rice and sugarcane farms. In the next two decades, as Thailand's industrial boom accelerated, they migrated to the Bangkok region to work in factories, on construction sites, and in a wide range of unskilled service industries. From the mid-1990s, with some decentralisation of industry to Khon Kaen and other regional centres, there was more work available within the region, enabling some household members to commute from the village. During this period, off- and non-farm employment came to be the major source of income for most households in the study village, particularly for smallholders with 2 ha or less. While this non-farm income enabled poor households to continue farming, the absence of workers contributed to a labour shortage in the village, adding to the impetus for mechanisation.

By the 1990s the sugar industry had partly relocated from the Central Plain to the Northeast, creating the incentive for farmers in the study village and elsewhere to take up this crop. Government control over and support for sugar prices made sugarcane production more remunerative and less risky than cassava production; hence, the area of cassava began to decline, though it remained a major land use. Unlike cassava, sugarcane was suited to the ecological conditions of the upper paddies; hence, farmers began to plant sugarcane on this land-type, contracting large fourwheeled tractors for tillage, thus reducing the area available for both wet-season rice cultivation and dry-season livestock grazing. In the study village, $55 \%$ of the upper paddies were converted to sugarcane production from 1983 to 1998. Sugarcane production was more labour-intensive 
than cassava, particularly at harvest, adding to the overall demand for labour in the village.

The 1990s also saw widespread investment in two-wheeled tractors for rice cultivation, a decade or two after their spread in the Central Plain. In 1983 there were only two two-wheeled tractors for the 234 households in the village. By 1998 there were 255 among 383 households. According to Barnaud et al. (2006), the main reason for this rapid uptake was the need to decrease the peak demand for labour at transplanting by speeding up the ploughing and puddling of the paddies. Farmers borrowed from the BAAC or sold their water buffaloes to pay for the purchase of the twowheeled tractors. In Khon Kaen Province as a whole, the buffalo population fell from 380,000 in 1987 to 80,000 in 2000. The disposal of the household's buffaloes also released one family worker from the care of these animals, freeing that person to seek more remunerative non-farm employment. In any case, the area of available grazing land was now in short supply due to the expansion of cassava and sugarcane.

Likewise, though not mentioned by Barnaud et al. (2006), the switch to direct seeding occurred in the Northeast a decade after its spread in the Central Plain. Konchan and Kono (1996) surveyed 100 farmers across different transects in an area to the southeast of Khon Kaen in 1994-1995. They found that, until the 1980s, most fields were transplanted. However, from the early 1990s, labour shortages induced farmers to use direct seeding, first in rainfed fields and then spreading to all field types. Dry seeding was the most common form used, but wet seeding was used in irrigated fields and in rainfed fields with a source of supplementary irrigation (e.g., pumping from a pond).

The growing shortage of labour and the increase in daily wages was also impacting on the costs of harvesting rice. This was exacerbated by revolutionary changes in rice varieties (Grandstaff et al. 2008). As described above, from 1977 the Rice Department introduced RD6, a photoperiod-sensitive glutinous rice variety with wide adaptability and excellent grain quality, which became the preferred subsistence crop, displacing most of the traditional varieties. In the study village only two of the 28 varieties of glutinous rice reported in 1983 were still found in 2002. In addition, the profitability of the non-glutinous jasmine rice (KDML105) meant that it was widely cultivated in the upper paddies as a cash crop. The two varieties are both medium-term varieties of moderate yield that mature at much the same time. Hence the harvest period, previously spread over two to three months, was concentrated (in any one 
farm) over two to three weeks in late November and early December, requiring farmers with more than 0.75 ha per family worker to hire labour for harvesting. This, combined with increasing wage rates as young people sought off- and non-farm work outside the village, added significantly to production costs, creating a strong incentive for the mechanisation of harvesting.

While combine harvesters had apparently not yet spread to the village at the time of the 2002 study by Barnaud et al. (2006), a more recent study by Poungchompu and Chantanop (2016) helps to bring the mechanisation story up to date. They conducted a survey in all 14 provinces of the Northeast Region in the 2014 wet season and the 2015 dry season, interviewing 85 operators and 729 farmers, including those with rainfed and irrigated rice farms. They found that over $70 \%$ of farmers used combine harvesters, all on a contract basis. From the early 2000s, contractors came from Central Thailand, transporting larger machines with a capacity to harvest 6-8 ha per day. These outside operators needed a local broker to assemble the rice area to be harvested to minimise the cost of travel between farms and because there was only a 30- to 35-day window for the wet-season rice harvest.

The profitability of providing harvesting services given the rapidly growing demand prompted local farmers with capital to acquire harvesters to service their neighbours, typically using smaller machines harvesting 2-5 ha per day. These local contractors did not require brokers; farmers requested their services directly and if the contractor proved reliable he would be rehired in subsequent seasons and other contractors would not encroach on his "territory". The higher costs facing outside operators and the government regulation of contract rates meant that the number of service providers from Central Thailand declined and they accounted for only $10 \%$ of operators in the Northeast in 2014-2015. Poungchompu and Chantanop (2016) found that replacing hand harvesting with the services of a combine harvester reduced farmers' harvesting costs from USD 270/ ha to USD 140/ha and that this was the main motivator for the widespread use of the new technology. The statistical likelihood of using a combine harvester increased with the education of the household head and the area of rice cultivated, and decreased with the size of the household.

From the late 1990s, following the Asian financial crisis and the slowdown in the non-farm economy, government support was provided to dig small, multipurpose farm ponds to promote more integrated and diverse farming systems and retain more people on the land (Barnaud et al. 2006). 
In 2002 there were 130 such ponds in the study village, ranging from 0.04 to 0.16 ha. Farmers with two-wheeled tractors could use them to power a low-lift axial-flow water pump to provide supplementary irrigation to rice nurseries and paddies, allowing earlier transplanting in some cases and helping to stabilise yields. The ponds were also used to rear fish, irrigate fruit and vegetables on a small scale, and provide drinking water for cattle.

Barnaud et al. (2006) summarised the agrarian change in the study village by classifying farming households into four main types:

1. "Very small farms with off-farm workers" (accounting for $75 \%$ of households) farmed 0.3 to 2 ha-not enough to fully employ family workers or to meet cash requirements. They had no investment capacity; had sold assets including upland fields, cattle, and buffaloes; and were indebted. They owned or rented a two-wheeled tractor for rice cultivation. Between 45 and $75 \%$ of their income was from off- or non-farm sources, whether from working on larger farms at the peak times for rice, sugarcane, or cassava, or from working outside the village in casual or permanent employment. Their net income in 2002 was USD 950 per worker.

2. "Small farms" (accounting for 20\% of households) had 2-3 ha, including some upland, which was enough to make farming more remunerative than working for wages. They hired out or hired in as little labour as possible and received only $25 \%$ of income from nonfarm sources. They accumulated little capital but had few debts. These households owned two-wheeled tractors and sometimes rented in a large four-wheeled tractor for cultivation of their upland crops. Their net income in 2002 was USD 1150 per worker.

3. "Large farms" (accounting for 3\% of households) had 3-4.5 ha, allowing them to fully employ family labour, meet their cash requirements, and accumulate capital, especially through intensive rearing of beef cattle for sale. They made extensive use of hired labour, owned a two-wheeled tractor, and rented in a four-wheeled tractor for upland cultivation. Nearly $100 \%$ of their income was from their own farming activities. Their net income in 2002 was USD 1600 per worker.

4. "Entrepreneurs" (accounting for 2\% of households) owned up to 5.5 ha and made extensive use of hired labour to farm their land. They had invested in heavy equipment (trucks and four-wheeled 
tractors) which they hired to other villagers, enabling them to fully employ family members, meet the household's cash requirements, and accumulate further capital. Around $80 \%$ of their income was from these farm service activities. Their net income in 2002 was USD 2800 per worker.

Thus the supply of manual labour, the ownership, and use of farm machinery, and the provision of contract services were closely related to the agrarian structure in the village that had emerged since the opening up of the region to commercial agriculture in the 1960s and the economic and demographic changes that had occurred in the 1970s and 1980s. Within the village, hired labour was provided by the $75 \%$ of poorer, smallfarm households for the $5 \%$ of better-off large-farm households, while the predominant flow of labour was into non-farm employment outside the village and the region. Two-wheeled tractors for rice farming were mostly owned by the farmers who used them, with some hiring by very small farmers, while combine harvesters, four-wheeled tractors for heavy upland cultivation, and trucks for transporting cash crops were in the hands of a few well-off entrepreneurial farmers specialising in contract service provision.

\section{Notes}

1. With the accession of King Mongkut in 1851 and the signing of the Bowring Treaty with Britain in 1855, Siam was opened up to global trade and the export of rice was formally allowed. This coincided with a long, steady rise in the price of rice, reflecting growing demand from other Asian countries. Siam's rice exports were overwhelmingly to the British entrepots of Hong Kong and Singapore (Owen 1971).

2. Isan was a relatively sparsely populated no-man's land between Bangkok and Vientiane until the 1827 revolt of Chao Anou, ruler of Vientiane, against his Thai overlords in Bangkok. After the revolt was crushed, tens of thousands of ethnic Lao from the left bank of the Mekong were forcibly settled in Isan where they could be more readily controlled. Over the subsequent century, more ethnic Lao came to be living in Isan than in Laos (Evans 2002: 25-32).

3 . These central markets have since ceased to exist throughout Thailand (Pongsrihadulchai 2018).

4. According to the Chaipattana Foundation (2017), established by Royal Charter in 1988, "Sufficiency Economy is a philosophy based on the fundamental principle of Thai culture. It is a method of development based on 
moderation, prudence, and social immunity, one that uses knowledge and virtue as guidelines in living. Significantly, there must be intelligence and perseverance which will lead to real happiness in leading one's life".

5. The official zoning of land into "suitable" and "unsuitable" for rice farming can be viewed online at the following site-http://agri-map-online.moac. go.th/.

6. Wages expressed in 2000 US dollars.

\section{REFERENCES}

ACI, 2005. The North East Thailand Rice Value Chain Study. Bethesda: Agrifood Consulting International.

ALRO, 2006. National Report on Agrarian Reform and Rural Development in Thailand. Submitted by Agricultural Land Reform Office to the International Conference on Agrarian Reform and Rural Development (ICARRD), 6-10 March 2006, Brazil.

Barnaud, C., Trébuil, G., Dufumier, M., and Suphanchaimart, N., 2006. Rural poverty and diversification of farming systems in upper Northeast Thailand. Moussons 9-10: 157-187.

Behrman, J. R., 1968. Supply Response in Underdeveloped Agriculture: A Case Study of Four Major Annual Crops in Thailand, 1937-1963. Amsterdam: North-Holland Publishing Company.

Burns, Anthony, 2004. Thailand's 20-Year Program to Title Rural Land. Background paper prepared for the World Development Report 2005.

Chaipattana Foundation, 2017. Philosophy of Sufficiency Economy. Available at http://www.chaipat.or.th/eng/concepts-theories/sufficiency-economy-newtheory.html (accessed 12 June 2019).

Chitibut, W., Poapongsakorn, N., and Aroonkong, D., 2014. Fertilizer Policy in Thailand. ReSAKSS Asia Policy Note 3. Washington, DC: IFPRI.

Chuasuwan, C., 2018. Rice Industry Outlook, 2018-2020. Bangkok: Krungsiri Research.

Dohrs, S. L., 1988. Commercial Agriculture and Equitable Development in Thailand. Southeast Asia Business Papers No. 5. Ann Arbor: Center for South and Southeast Asia Studies, University of Michigan.

Ekasingh, B., Sungkapitux, C., Kitchaicharoen, J., and Suebpongsang, P., 2008. Competitive Commercial Agriculture in the Northeast of Thailand. Chiang Mai: Department of Agricultural Economics and the Multiple Cropping Centre, Faculty of Agriculture, Chiang Mai University.

Evans, G., 2002. A Short History of Laos: The Land in Between. Sydney: Allen and Unwin.

Falvey, Lindsay, 2000. Thai Agriculture: Golden Cradle of Millennia. Bangkok: Kasetsart University. 
FAO, 2019. Country fact sheet on food and agriculture policy trends (Thailand). Food and Agriculture Organization of the United Nations. Available at http:// www.fao.org/3/I8683EN/i8683en.pdf (accessed 5 May 2019).

Floch, P., and Molle, F., 2009. Pump Irrigation Development and Rural Change in Northeast Thailand. Working Paper, Mekong Program on Water, Environment and Resilience (M-POWER). Chiang Mai: University of Natural Resources and Applied Life Sciences, Institut de Recherche pour le Développement, International Water Management Institute.

Floch, P., and Molle, F., 2013. Irrigated agriculture and rural change in Northeast Thailand: reflections on present developments. In R. Daniel, L. Lebel, and K. Manorom, eds., Governing the Mekong: Engaging in the Politics of Knowledge, pp. 188-212. Petaling Jaya: Strategic Information and Research Development Centre.

Grandstaff, T. B., Grandstaff, S., Limpinuntana, V., and Suphanchaimat, N., 2008. Rainfed revolution in Northeast Thailand. Southeast Asian Studies 46: 289-376.

Heckman, C. W., 1979. Rice Field Ecology in Northeastern Thailand: The Effect of Wet and Dry Seasons on a Cultivated Aquatic Ecosystem. The Hague: Dr. W. Junk B.V., Publishers.

Kasem, Sukallaya, and Thapa, Gopal, 2012. Sustainable development policies and achievements in the context of the agriculture sector in Thailand. Sustainable Development 20: 98-114.

Konchan, S., and Kono, Y., 1996. Spread of direct seeded lowland rice in Northeast Thailand: farmers' adaptation to economic growth. Southeast Asian Studies 33: 523-546.

Molle, F., Floch, P., Promphakping, B., and Blake, D. J. H., 2009. The 'greening of Isaan': politics, ideology and irrigation development in the northeast of Thailand. In F. Molle, T. Foran, and M. Kakonen, eds. Contested Waterscapes in the Mekong Region: Hydropower, Livelihoods and Governance, pp. 253-282. London: Earthscan.

Mordor Intelligence, 2019. Fertilizers Market-Thailand. Industry Growth, Trends, and Forecasts 2017-2022. Available at https://www.mordorintelligence.com/industry-reports/thailand-fertilizers-marke (viewed 11 June 2019).

National Statistics Office, 2008. Agriculture inter-censal survey in 2008 for whole kingdom. Available at http://service.nso.go.th/nso/nsopublish/service/ agricult/ais-wk/ais-wk.pdf (accessed 2 July 2012).

OAE, 2011. Agricultural Economics Outlook 2011-2012. Thailand: Office of Agricultural Economics. Available at http://www.oae.go.th/bapp/download/gdp/outlook\%202011-12.pdf (accessed 12 January 2012).

Office of Agricultural Economics, 2018a. Agricultural Statistics of Thailand. Office of Agricultural Economics, Ministry of Agriculture and Cooperatives, Thailand. Available at http://www.oae.go.th/assets/portals/1/files/jounal/2562/yearbook2561.pdf (accessed 4 May 2019). 
Office of Agricultural Economics, 2018b. Agricultural Information. Office of Agricultural Economics, Ministry of Agriculture and Cooperatives, Thailand. Available at http://www.oae.go.th/assets/portals/l/files/jounal/2562/ commodity2561.pdf (accessed 4 May 2019).

Owen, N. G., 1971. The rice industry of Mainland Southeast Asia 1850-1914. Journal of the Siam Society 59: 78-143.

Pongsrihadulchai, A., 2018. Thailand's Rice Industry and Current Policies towards High Value Rice Products. Paper submitted for International Seminar on Promoting Rice Farmers' Market Through Value-Adding Activities, 6-7 June 2018, Kasetsart University, Bangkok.

Poungchompu, S., and Chantanop, S., 2016. Economic aspects of rice combine harvesting service for farmers in Northeast Thailand. Asian Social Science 12: 210-211.

Rabobank, 2003. Thai Rice: Time for a Sustainable Development. Food and Agribusiness Research. Bangkok: Rabobank International.

Rambo, A. T., 2017. The agrarian transformation in Northeastern Thailand: a review of recent research. Southeast Asian Studies 6: 211-245.

Rigg, J., Salamanca, A., and Parnwell, M., 2012. Joining the dots of agrarian change in Asia: a 25 year view from Thailand. World Development 40: 1469-1481.

Setboonsang, S., 1996. Rice research priorities in Thailand. In R. E. Evenson, R. W. Herdt, and M. Hossain, eds. Rice Research in Asia: Progress and Priorities. Los Banos: International Rice Research Institute.

Sunsuk, D., 2016. Isaan farmers and local officials slam failed rice policy. The Isaan Record, 25 October 2016.

Viboon, Thepent, and Chamsing, Anucit, 2009. Agricultural Mechanization Development in Thailand. Fifth Session of the Technical Committee of APCAEM, 14-16 October 2009. Los Banos: APCAEM.

Wada, H., 2005. Managing sandy soils in Northeast Thailand. In Proceedings of Conference on Management of Tropical Sandy Soils for Sustainable Agriculture, 27 November to 2 December 2005, Khon Kaen, Thailand. Available at http:// www.fao.org/3/agl25e/AG125E11.htm (accessed 28 May 2019).

Welcher, P., 2017. Thailand: Rice Market and Policy Changes over the Past Decade. GAIN Report No. TH7011. Bangkok: USDA Foreign Agricultural Service.

Wiboonpongse, A., and Chaovanapoonphol, Y., 2001. Agribusiness Research on Marketing System in Thailand. Chiangmai: Multiple Cropping Center, Chiangmai University. 
Open Access This chapter is licensed under the terms of the Creative Commons Attribution 4.0 International License (http://creativecommons.org/licenses/ by $/ 4.0 /$ ), which permits use, sharing, adaptation, distribution and reproduction in any medium or format, as long as you give appropriate credit to the original author(s) and the source, provide a link to the Creative Commons licence and indicate if changes were made.

The images or other third party material in this chapter are included in the chapter's Creative Commons licence, unless indicated otherwise in a credit line to the material. If material is not included in the chapter's Creative Commons licence and your intended use is not permitted by statutory regulation or exceeds the permitted use, you will need to obtain permission directly from the copyright holder.

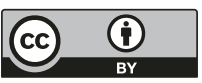

